\title{
Population dynamics of the edible rock oyster Saccostrea cucullata (Born, 1778) along the south-west coast of India
}

\author{
S. YAMBEM TENJING \\ Department of Biosciences, Mangalore University, Mangalagangothri, Mangaluru - 574 199, Karnataka, India \\ e-mail: yambemtenjing@gmail.com
}

\begin{abstract}
For the management of molluscan stocks, knowledge of various population parameters and exploitation level of the population are needed. The present study assessed the population dynamics on the rock oyster Saccostrea cucullata (Born, 1778) in Karnataka State, south India. The specimens of S. cucullata were collected from Baindur rocky beach at monthly intervals from June 2010 to May 2011. Asymptotic length $\left(\mathrm{L}_{\infty}\right)$ estimated was $57.8 \mathrm{~mm}$ and growth coefficient $(\mathrm{K})$ was estimated at 1.4 year $^{-1}$. The sizes attained were $45.30,54.72$ and $57.04 \mathrm{~mm}$ at the end of first, second and third years of age, respectively. Total mortality $(\mathrm{Z})$ was 5.24 year $^{-1}$. Natural mortality $(\mathrm{M})$ and fishing mortality $(\mathrm{F})$ were 1.40 and 3.84 year $^{-1}$ respectively. The life span of $S$. cucullata was estimated as 2.5 years approximately. Exploitation level (E) was computed as 0.73 , indicating that the fishery of $S$. cucullata in the coastal waters of Karnataka is overexploited.
\end{abstract}

Keywords: Age, Exploitation, Growth, Karnataka, Mortality, Recruitment, Rock oyster, Saccostrea cucullata

\section{Introduction}

The rock oyster Saccostrea cucullata (Born, 1778) is a tropical edible species widely distributed in the littoral zone of Indo-Pacific, Eastern Atlantic and the Mediterranean (Poutiers, 1998). In northern Australia, China, Thailand and India, this oyster is cultivated in backwaters and is quite popular in local markets (Jarayabhand and Thavornyutikar, 1995; Nell, 2001). S. cucullata is abundant on the south-west coast of India, where it often forms a distinct patch from mid to upper balanoid zone. Although not of commercial importance in India, $S$. cucullata is exploited by coastal fisherfolk who consume it and forms one of the major component in diets of these people when compared to other intertidal organisms.

Dye (1989) studied ecology of this species from the east coast of southern Africa and it is commercially exploited in Kenya. The east coast of southern Africa marks the southern limit of its distribution, but it is abundant around the Indian ocean (Kilburn and Rippey, 1982). Very little is known on the biology of $S$. cucullata in India. Recently, the ecology of $S$. cucullata was studied from the Sundarbans (Bhattacharyya et al., 2010). Growth was studied from Ashtamudi Lake, Kerala and Sundarbans, West Bengal (Kripa and Salih, 1999; Bhattacharyya et al., 2010). Seasonal variation in the biochemical composition and reproductive cycle were studied from the Indian Sundarbans and Mangalore respectively (Mitra et al., 2008; Sukumar and Joseph, 1988). Bivalve growth is mostly estimated by measuring the shell dimensions and rings or the volume of the animal (Deval, 2001). Allometry involves study of the change in proportion of various parts of an organism as a consequence of growth (Reiss, 1989).

Competitors, natural enemies including predators and environmental stresses are the major causes of mortality, other than natural senescence in oysters (Quayle, 1980). Much research has been undertaken to relate mortality of oyster with various physical and biological factors, namely temperature (Helen, 1997), salinity variations (Kripa and Salih, 1999), mud and silt accumulation (Awati and Rai, 1931), pollution (Wang et al., 2011), food deficiency (Bhattacharyya et al., 2010), competition for space and food (Lin and Tang, 1980), predation (Taylor, 1990; Helen, 1997), parasitic infections (Robert et al., 1991) and epibiont interference (Awati and Rai, 1931). Predation is an important factor causing oyster mortality (Helen, 1997). Although literature on rock oysters are available from all the Indian coastal regions, there seems to be very little attention paid towards the study on their population dynamics. The present paper gives data on growth, age, recruitment, mortality and exploitation rate of the edible rock oyster, S. cucullata from Karnataka.

\section{Materials and methods}

Study area

Karnataka State located in the southern part of India has three coastal districts viz., Dakshina Kannada, Udupi and Uttara Kannada. The study area in Baindur (Fig. 1) 
is a rocky shore beach located near to the Someshwara Temple, in Udupi District (Fig. 1).

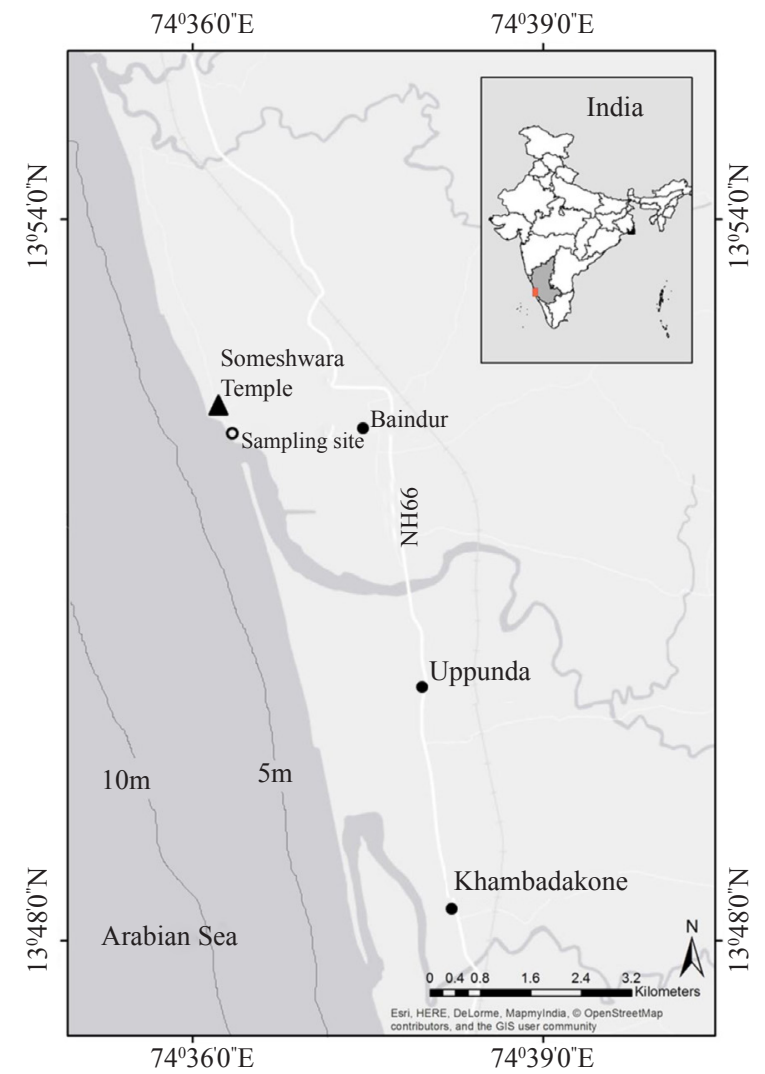

Fig. 1. Location of sampling site in Baindur, along the Karnataka coast

\section{Sample processing}

S. cucullata samples (Fig. 2) were collected from

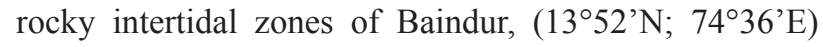
from June 2010 to May 2011. Oysters were collected with the help of hammer and chisel, as the colonies of this oyster grow on hard rocks making them very difficult to remove. The oyster samples collected were cleaned with tap water and blotted using a blotting paper. A total of 2328 S. cucullata ranging in size from 4.7 to $55.2 \mathrm{~mm}$ were analysed. The length (the maximum distance along the long axis of the shells) was determined to the nearest of $0.1 \mathrm{~mm}$ (FAO, 1998).

\section{Data analysis}

For estimating von Bertalanffy growth parameters viz., asymptotic length $\left(\mathrm{L}_{\infty}\right)$ and growth constant $(\mathrm{K})$, the length measurement data for one year were pooled month-wise and grouped into length classes of $4.2 \mathrm{~mm}$ intervals and analysed using ELEFAN (Electronic Length Frequency Analysis) from FiSAT software (Gayanilo et al., 2005). Estimates of $\mathrm{L}_{\infty}$ and $\mathrm{K}$ were used to estimate

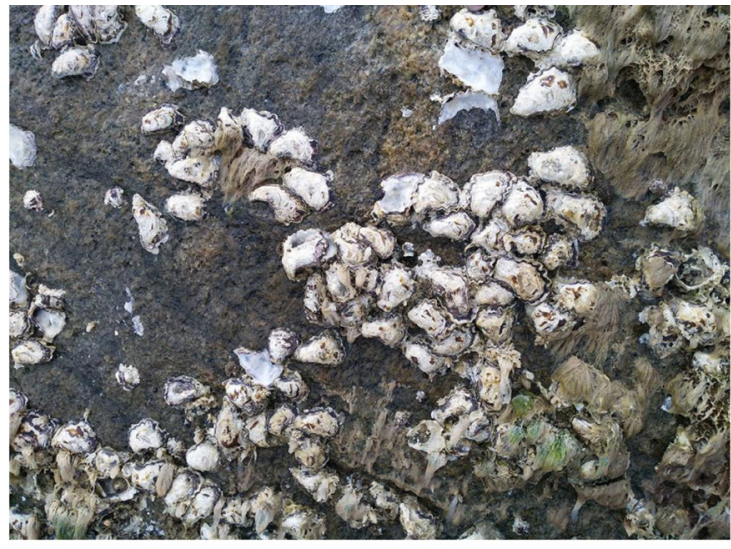

Fig. 2. Oyster bed of S. cucullata at Baindur, Karnataka

the growth performance index (ø) (Pauly and Munro, 1984) of $S$. cucullata using the equation, $\varnothing^{\prime}=2 \log _{10} \mathrm{~L}_{\infty}+$ $\log _{10} \mathrm{~K}$. From the values of $\mathrm{L}_{\infty}$ and $\mathrm{K}$, the growth curve was fitted using the von Bertalanffy growth equation (von Bertalanffy, 1938). The von Bertalanffy growth function (VBGF) is defined by the equation, $\mathrm{L}_{\mathrm{t}}=\mathrm{L}_{\infty}\left[1-e^{-K(t-}\right.$ ${ }^{t o}$ ] , where $\mathrm{L}_{\mathrm{t}}$ is the length at time $t, e$ is the base of the natural logarithm, $t$ the time of observation and $t_{o}$ is the hypothetical age when the length is zero (Newman, 2002). The parameter $t_{o}$ of the growth equation was estimated using the equation (Pauly 1983): $\log \left(-t_{o}\right)=-0.3922-$ $0.2752 \log \left(\mathrm{L}_{\infty}\right)-1.038 \log (\mathrm{K})$.

Taking into account that non-linear growth functions are difficult to compare, several authors demonstrated the suitability of composite indices for overall growth performance (OGP) for inter- and intra-specific comparisons (Pauly, 1979; Munro and Pauly, 1983). The OGP equation derived was OGP $=\log \left[\mathrm{K}\left(\mathrm{L}_{\infty}\right)^{3}\right]$. The total mortality $(\mathrm{Z})$ was estimated from length converted catch curve method following Pauly (1984). The natural mortality coefficient $(\mathrm{M})$ was determined using $\mathrm{M} \approx \mathrm{K}$ approximation (Gayanilo and Pauly, 1997; Jayawickrema and Wijeyaratne, 2009). and fishing mortality coefficient (F) was estimated by subtracting $\mathrm{M}$ from $\mathrm{Z}$. The exploitation rate $(\mathrm{E})$ was calculated from the equation of Gulland (1965), i.e., $\mathrm{E}=\mathrm{F} / \mathrm{Z}=\mathrm{F} / \mathrm{F}+\mathrm{M}$. The recruitment pattern was obtained by projecting the length-frequency data backwards on the time axis using growth parameters (Moreau and Cuende, 1991).

\section{Results}

\section{Growth parameters}

Asymptotic length $\left(\mathrm{L}_{\infty}\right)$ estimated was $57.8 \mathrm{~mm}$ and the growth coefficient $(\mathrm{K})$ was 1.4 years for $S$. cucullata. The growth curve using these two parameters is shown over the length frequency distribution in Fig. 3. The $t_{0}$ obtained was -0.094 and growth performance index $\left(\varnothing^{\circ}\right)$ 
was found to be 3.67 (Fig. 4) in the present study. The $95 \%$ confidence interval for maximum length $(56.16 \mathrm{~mm})$ was between 53.06 and $59.25 \mathrm{~mm}$. The calculated overall growth performance (OGP) of $S$. cucullata was 5.43.

Age and growth

Using the growth parameters, growth and age of $S$. cucullata were calculated. The growth rate and the absolute increase in age are presented in Fig. 5. The sizes attained by $S$. cucullata were 45.30, 54.72 and $57.04 \mathrm{~mm}$ at the end of first, second and third years of age, respectively. The average growth rates for $S$. cucullata from first to third years were $3.78,0.78$ and $0.19 \mathrm{~mm}$ respectively. The lifespan of this species reached upto approximately 2.5 years.

\section{Recruitment pattern}

The recruitment pattern of $S$. cucullata was continuous throughout the year with two major peaks in April and September (Fig. 6). The percent recruitment varied from 1.03 to 18.18 in the present study. The highest

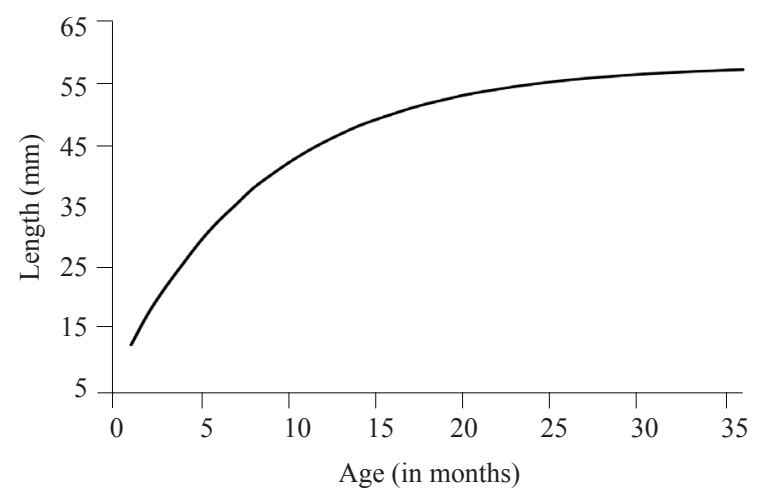

Fig. 5. Plot of age and growth of S. cucullata based on computed growth parameters

and lowest recruitment percentage were observed in April and January respectively.

\section{Mortality and exploitation}

The total mortality $(Z)$ was estimated as 5.24 year $^{-1}$ using the length converted catch curve (Fig.7). The natural

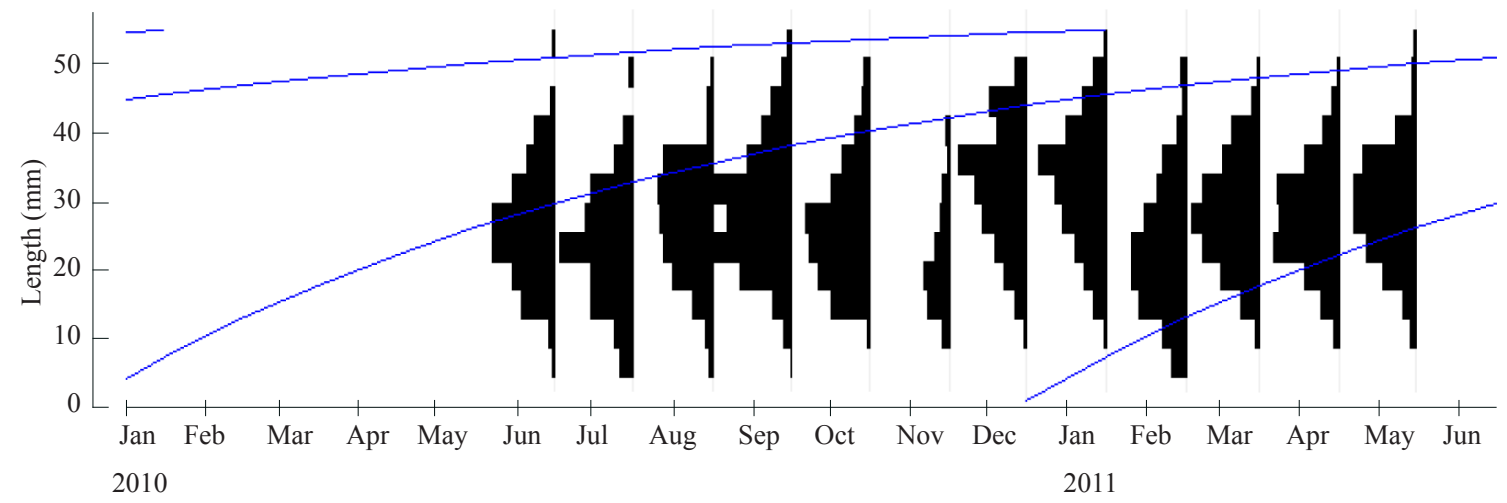

Fig. 3. Growth curves of $S$. cucullata as superimposed on the length frequency distribution using ELEFAN-I

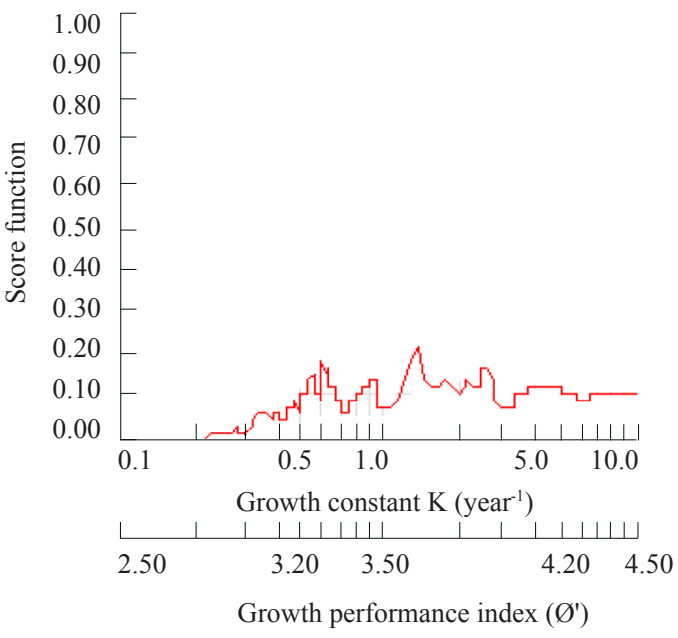

Fig. 4. Estimation K of S. cucullata in Karnataka coast

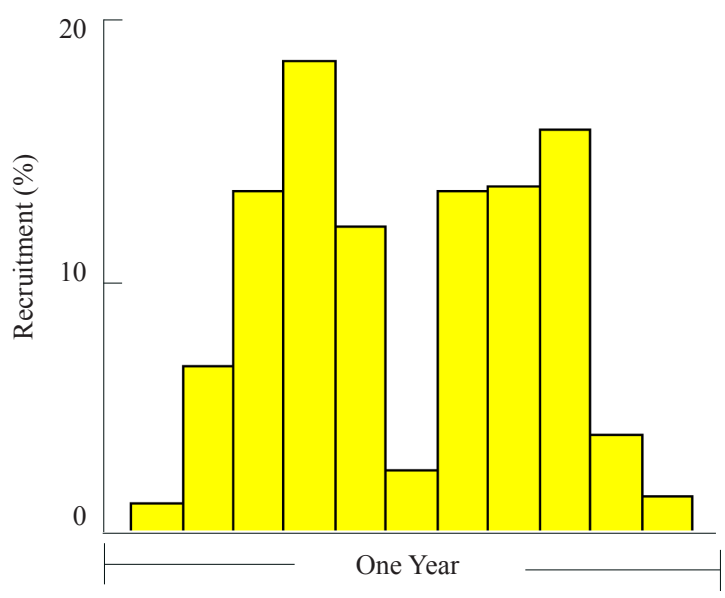

Fig. 6. Recruitment pattern of S. cucullata 
mortality (M) and fishing mortality (F) were 1.40 and 3.84 year $^{-1}$ respectively. exploitation rate $(\mathrm{E})$ obtained for S. cucullata in the present study was 0.73 .

\section{Virtual population analysis (VPA)}

The length structured virtual population analysis (VPA) of S. cucullata is presented in Fig. 8 which indicated that the minimum and maximum fishing mortalities were 0.0856 and 4.4486 year $^{-1}$ at themidlengths of 6.6 and $48.5 \mathrm{~mm}$ respectively. The fishing mortality (F) was high over the mid lengths from 35.9 to $52.7 \mathrm{~mm}$.

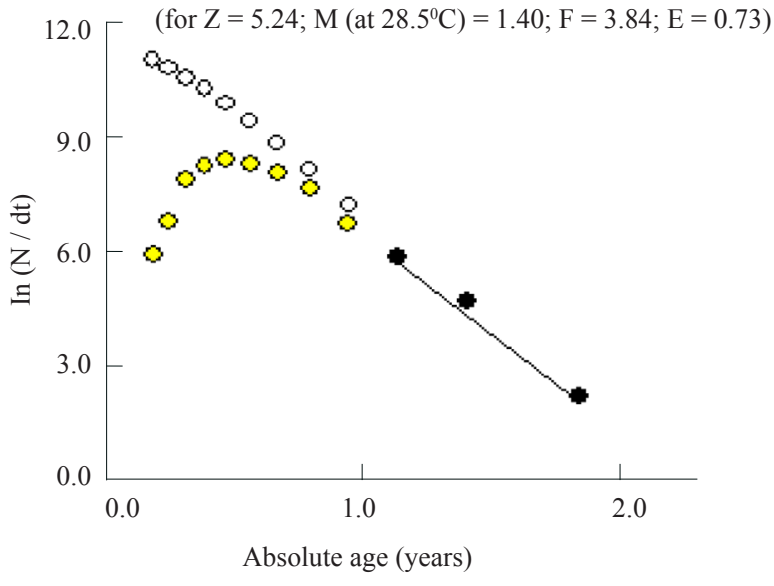

Fig. 7. Mortality estimation of S. cucullata using Pauly's linearised length converted catch curve method

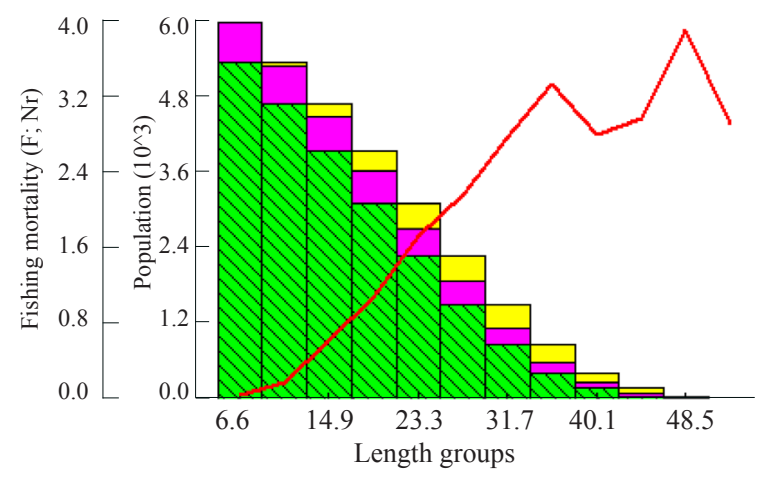

Fig. 8. Length-structured virtual population analysis of S. cucullata

\section{Discussion}

In the present study, the $\mathrm{L}_{\infty}$ was $57.8 \mathrm{~mm}$ and $\mathrm{K}$ was 1.4 year $^{-1}$ when the $t_{o}$ was -0.094 year. From these parameters, growth rate and age were calculated. Arkhipkin et al. (2017) reported the growth in terms of shell height of S. cucullata pooled from all sampling sites in Ascension Island which was described by the von Bertalanffy growth model. The population asymptotic average shell height $\left(\mathrm{L}_{\infty}\right)$ reported by Arkhipkin et al. (2017) was $86.06 \mathrm{~mm}$, the growth coefficient, $\mathrm{K}$ was 0.234 and the $t_{o}$ was -0.69 . Among these three parameters, the value of $\mathrm{L}_{\infty}$ is much higher than that of the $\mathrm{L}_{\infty}$ reported in the present study. As reported in mussels (Perna viridis, Modiolus auriculatus) and clams (Donax scortum, D. faba), the fastest growth in S. cucullata was observed during the first year of ontogeny (Singh et al., 2011; Tenjing et al., 2016, 2017a, b; Hemachandra et al., 2017).

Morton (1990) and Chiu (1997) found that S. cucullata has a short life span, especially in the peripheries of their ranges, with the majority of animals living just over two years. The longevity of this species estimated in the present study was 2.5 years. It has been suggested that such a shortlife cycle in this oyster is usually a result of harsh environmental conditions with exposure to pollution and high temperatures in nearshore areas (Krishnakumari et al., 1990; Davenport and Wong, 1992; Mtanga and Machiwa, 2007).

Recruitment of $S$. cucullata involves a sequence of steps viz., reproduction, larval dispersal, settlement and survival of spat. Recruitment failure may result from problems arising at any of these steps. It seems unlikely that lack of gonadal output is the primary cause of poor recruitment. The highest and lowest recruitment percentages were observed during summer and winter respectively in the present study. Lasiak (1986) studied reproduction of this species in Transkei coast of South Africa, which indicated a well defined spawning period from February to March during which over $40 \%$ of the animals examined were in spawning condition. The answer must therefore be sought in the vagaries of larval dispersal and/or post-settlement survival. Numerous factors affect post-settlement survival. Survival rate of other species like barnacle cyprids totally depends on temperature (Lewis, 1986). Lasiak (1986) reported that one of the most important physical factors affecting recruitment of bivalves, is high temperature on rock surface during hot days which leads to associated desiccation stress. Intertidal oysters often suffer from high temperature and face mortality when abnormally high temperatures coincide with unusually low mid-day tides (Dakin et al., 1952). Rocky shores along with its ambient environment are conducive for oysters and their larval settlement. Limpets are important predators in the upper balanoid zone of rock (Dye, 1988). These gastropods constitute a source of indirect predation by bulldozing newly settled larvae (Denley and Underwood, 1979; Branch, 1981; Underwood et al.,1983). According to Quayle (1980), predators of oysters are fish, crab, snails, starfish and flatworms. Only young ones which settle in crevices or small depressions in the rock surface, or which grow rapidly to a size which exceeds the range over which bulldozing is effective, will 
survive and get recruited to the adult population. This number appeared to be very small in the present study. Dye (1989) stated that Thais dubia and Morula granulata are the major molluscan predators of $S$. cucullata in east coast of southern Africa. The low natural mortality (M) found in nature reserves suggests that the effect is minimal. The $M$ value of 1.4 estimated in the the present study could be due to predation in the study area. $S$. cucullata is consumed by coastal fisherfolk in India (Maran and Ayyakkannu, 2002). According to Gulland (1965), the yield is optimised when $\mathrm{F}=\mathrm{M}$. On the other hand, when $\mathrm{E}$ is more than 0.5 , the stock is overexploited. In the study area, S. cucullata is consumed by fisherfolk regularly and the oyster bed in the rocky habitat of Baindur was found to be subjected to overexploitation $(\mathrm{E}=0.73)$.

Temperature might interact with other environmental attributes, such as salinity and food availability, as a main factor to define the growth and age. The present results give an overall idea about the relative growth and age of $S$. cucullata. However, for specific biological evaluation of the growth progression, long-term monitoring is required, which would help to understand the dynamics of this species.

\section{Acknowledgements}

The author is grateful to the authorities of Mangalore University, Karnataka, for the facilities provided and to the University Grants Commission, New Delhi for providing the financial assistance [BSR-UGC Meritorious Fellowship No. 4-1/2008(BSR)].

\section{References}

Arkhipkin, A., Boucher, E., Gras, M. and Brickle, P. 2017. Variability in age and growth of common rock oyster Saccostrea cucullata (Bivalvia) in Ascension Island (Central East Atlantic). J. Mar. Biol. Ass. U.K., 97: 735-742.

Awati, P. R. and Rai, H. S. 1931. The Indian zoological memoirs on Indian animal types III.Ostrea cucullata (The Bombay oyster). Methodist Publishing House, Lucknow, India. $107 \mathrm{pp}$.

Bhattacharyya, S., Panigrahi, A., Mitra, A. and Mukherjee, J. 2010. Effect of physico-chemical variables on the growth and condition index of the rock oyster, Saccostrea cucullata (Born) in the Sundarbans, India. Indian J. Fish., 5(3): 13-17.

Branch, G. M. 1981. The biology of limpets: physical factors, energy-flow and ecological interactions. Oceanogr. Mar. Biol. Annu. Rev., 19: 235-379.

Chiu, M. C. 1997. The ecology and energetics of Saccostrea cucullata (Born): (Bivalvia: Ostreidae) in Hong Kong. Ph. D. thesis, University of Hong Kong, Hong Kong.
Dakin, W. J., Bennet, I. and Pope, E. 1952. Australian seashores. Angus and Robertson Ltd., London, UK, 372 pp.

Davenport, J. and Wong, T. M. 1992. Effects of temperature and aerial exposure on three tropical oyster species, Crassostrea belcheri, Crassostrea iradelei and Saccostrea cucullata. J. Therm. Biol.,17(3): 135-139.

Denley, E .J. and Underwood, A. J. 1979. Experiments on factors influencing settlement, survival and growth of two species of barnacles in New South Wales. J. Exp. Mar. Biol. Ecol., 36(3): 269-293.

Deval, M. C. 2001. Shell growth and biometry of the striped venus Chamelea gallina (L) in the Marmara Sea, Turkey. J. Shellfish Res., 20(1): 155-159.

Dye, A. H. 1988. Rocky shore surveillance on the Transkei coast of southern Africa: Temporal and spatial variability in the balanoid zone at Dwesa. Afr. J. Mar. Sci.,7(1): 87-99. DOI: $10.2989 / 025776188784379143$.

Dye, A. H. 1989. Studies on the ecology of Saccostrea cucullata (Born, 1778) (Mollusca: Bivalvia) on the east coast of southern Africa. Afr. J. Mar. Sci., 24(2): 110-115. DOI: 10.1080/02541858.1989.11448142.

FAO 1998. The living marine resources of the Western Central Pacific: Seaweeds, corals, bivalves and gastropods. Food and Agriculture Organization, Rome, Italy, 686 pp.

Gayanilo, J. F. C., Sparre, P. and Pauly, D. 2005. The FAOICLARM stock assessment tools (FiSAT) user's guide, FAO computerised information series (Fisheries). Food and Agriculture Organization, Rome, Italy, 168 pp.

Gayanilo, J. F. C. and Pauly, D. 1997. FAO-ICLARM stock assessment tools (FiSAT) reference manual. Food and Agriculture Organization, Rome, Italy, $262 \mathrm{pp}$.

Gulland, J. A. 1965. Estimation of mortality rates. Annex to Arctic fisheries working group report ICES C.M./1965/D:3. (mimeo). In: Cushing, P. H. (Ed.), Key papers on fish populations. IRL Press, Oxford, UK, p. 231-241.

Helen, C. M. C. 1997. The ecology and energetics of Saccostrea cucullata (Born) (Bivalvia: Ostreidae) in Hong Kong. Ph.D. thesis, The University of Hong Kong, Hong Kong.

Hemachandra, Tenjing, S.Y. and Thippeswamy, S. 2017. Population dynamics of the Asian green mussel Perna viridis (L.) from St. Mary's Islands off Malpe, India. Indian J. Geo-Mar. Sci., 46(8): 1659-1666.

Jarayabhand, P. and Thavornyutikarn, M. 1995. Realised heritability estimation on growth rate of oyster, Saccostrea cucullata (Born, 1778). Aquaculture, 138: 111-118. https:// doi.org/10.1016/0044-8486(95)01080-7.

Jayawickrema, E. M. and Wijeyaratne, M. J. S. 2009. Distribution and population dynamics of the edible bivalve species Meretrix casta (Chemnitz) in the Dutch canal of Sri Lanka. Sri Lanka J. Aquat. Sci., 14: 29-44. 
Kilburn, R. and Rippey, E. 1982. Sea shells of southern Africa. Macmillan, Johannesburg, South Africa, 249 pp.

Kripa, V. and Salih, K. Y. M. 1999. Growth and reproduction of the rock oyster Saccostrea cucullata (Born) in Ashtamudi Lake, Kerala. Proceedings of the Fourth Indian Fisheries Forum, 24-28 November 1996, Kochi, Kerala, India, p. 371-372.

Krishnakumari, L., Nair, V. R. and Govindan, K. 1990. Some aspects on growth and condition index of Saccostrea cucullata (Born), Cerithium rubus (Desh) and Tellina angulata Gmelin from Bombay coast. J. Indian Fish. Ass., 20: 21-29.

Lasiak, T. 1986. The reproductive cycles of the intertidal bivalves Crassostrea cucullata (Born, 1778) and Perna perna (Linnaeus, 1758) from the Transkei Coast, Southern Africa. The Veliger, 29(2): 226-230.

Lewis, J. R. 1986. Latitudinal trends in reproduction, recruitment and population characteristics of some rocky littoral molluses and cirripedes. Hydrobiologia, 142: 1-13.

Lin, Y. S. and Tang, R. C.1980. Biological studies on cultured oysters in Penghu. Bull. Inst. Zool. Acad. Sin., 19: 15-22.

Maran, B. A. V. and Ayyakkannu, K. 2002. Parasitic copepods in Saccostrea cuculatta (Born 1778), a mangrove associated oyster at Pichavaram backwaters, south-east coast of India. Proceedings of the National Seminar on Creeks, Estuaries and Mangroves: Pollutions and conservation, 28-30 November 2002, Thane, Maharashtra, India, p. 132-134.

Mitra, A., Basu, S. and Banerjee, K. 2008. Seasonal variation in biochemical composition of edible oyster (Saccostrea cucullata) from Indian Sundarbans. Fishery Technol., 45(2): 209-216.

Morton, B. 1990. Life cycle and sexual strategy of Saccostrea cucullata (Bivalvia: Ostreidae) from a Hong Kong mangrove. Am. Malacol. Bull., 8: 1-8.

Mtanga, A. and Machiwa, J. F. 2007. Heavy metal pollution levels in water and oysters, Saccostrea cucullata from Mzingacreek and Ras Dege mangrove ecosystems, Tanzania. Afr. J. Aquat. Sci., 32: 235-244.

Moreau, J. and Cuende, X. 1991. On improving the resolution of the recruitment patterns of fishes. Fishbyte, 9: 45-46.

Munro, J. L. and Pauly, D. 1983. A simple method for comparing the growth of fishes and invertebrates. Fishbyte, 1: 5-6.

Nell, J. A. 2001. The history of oyster farming in Australia. Mar. Fish. Rev., 63: 14-25.

Newman, S. J. 2002. Growth, age estimation and preliminary estimates of longevity and mortality in the moses perch, Lutjanus russelli (Indian ocean form), from continental shelf waters off north-western Australia. Asian Fish. Sci., 15: 283-294.
Pauly, D. 1979. Gill size and temperature as governing factors in fish growth: a generalization of the von Bertalanffy's growth formula. Ber. Inst. Meereskd. Univ. Kiel., 63: 1-156.

Pauly, D. 1983. Some simple methods for the assessment of tropical fish stocks. FAO Fish. Tech. Pap., 234: 1-52.

Pauly, D. 1984. Fish population dynamics in tropical waters: a manual for use with programmable calculator. International Centre for Living Aquatic Resources Management, Manila, Philippines, $325 \mathrm{pp}$.

Pauly, D. and Munro, J. L. 1984. Once more on the comparison of growth in fish and invertebrates. Fishbyte, 2: 1-21.

Poutiers, J. M. 1998. Bivalves: Acephala, Lamellibranchia, Pelecypoda. In: Carpenter, K. E. and Niem, V. H. (Eds.), FAO species identification guide for fishery purposes - the living marine resources of the Western Central Pacific: Seaweeds, corals, bivalves and gastropods,vol. 1. Food and Agriculture Organization, Rome, Italy, p. 123-362.

Quayle, D. B. 1980. Tropical oysters: culture and methods. International Development Research Centre, Ottawa, Canada, 80 pp.

Reiss, M. J. 1989. The allometry of growth and reproduction. Cambridge University Press, New York, USA, 182 pp.

Robert, R., Borel, M., Pichot, Y. and Trut, G. 1991. Growth and mortality of the European oyster Ostrea edulis in the Bay of Arcachon (France). Aquat. Living Resour., 4: 265-274. https://doi.org/10.1051/alr:1991028.

Singh, Y. T., Krishnamoorthy, M. and Thippeswamy, S. 2011. Population ecology of the wedge clam Donax faba (Gmelin) from the Panambur beach, near Mangalore, south-west coast of India. J. Theor. Exp. Biol., 7: 171-182.

Sukumar, P. and Joseph, M. M. 1988. Annual reproductive cycle of the rock oyster Saccostrea cucullata (von Born). Proceedings of the First Indian Fisheries Forum, Asian Fisheries Society Indian Branch, Mangaluru, Karnataka, India, p. 207-210.

Taylor, J. D. 1990. Field observations of prey selection by the muricid gastropods Thais clavigera and Morula musiva feeding upon the intertidal oyster Saccostrea cucullata. In: Morton, B. (Ed.), Proceedings of the Second International Marine Biological Workshop: The marine flora and fauna of Hong Kong and Southern China. Hong Kong University Press, Hong Kong, p. 837-855.

Tenjing, S.Y., Thippeswamy, S. and Narasimhaiah, N. 2016. A first study on growth, mortality and survivourship of the eared horse mussel, Modiolus auriculatus (Krauss, 1848) from India. Indian J.Geo-Mar. Sci., 45: 323-332.

Tenjing, S. Y. 2017a. Population dynamics of Donax faba (Family: Donacidae) in the coastal waters of Padukere, Karnataka (India). Iran J. Fish. Sci., 16: 411-421. 
Tenjing, S. Y. 2017b. Status of population dynamics of the Asian wedge clam, Donax scortum (Bivalvia: Donacidae): a first report from Asia. J. Mar. Biol. Ass. UK, 97: 1635-1642.

Underwood, A. J., Denley, E. J. and Moran, M. J. 1983. Experimental analysis of the structure and dynamics of rocky intertidal communities in New South Wales. Oecologia, 56: 202-219. doi: 10.1007/BF00379692. von Bertalanffy, L. 1938. A quantitative theory of organic growth. Hum. Biol.,10: 181-213.

Wang, M., Xu, Y., Pan, S., Zhang, J., Zhong, A., Song, H. and Ling, W. 2011. Long-term heavy metal pollution and mortality in a Chinese population: an ecologic study. Biol. Trace Elem. Res., 142: 362-379. doi: 10.1007/s12011-0108802-2. 